\title{
Dendrochronologically dated pine stumps document phase-wise bog expansion at a northwest German site between ca. 6700 and ca. 3400 BC
}

\author{
Inke Elisabeth Maike Achterberg ${ }^{1}$, Jan Eckstein ${ }^{2}$, Bernhard Birkholz ${ }^{3}$, Andreas Bauerochse ${ }^{4}$, and \\ Hanns Hubert Leuschner ${ }^{1}$ \\ ${ }^{1}$ Department for Palynology and Climate Dynamics, University of Göttingen, 37073 Göttingen, Germany \\ ${ }^{2}$ Independent researcher: Arnoldiweg 20, 37083 Göttingen, Germany \\ ${ }^{3}$ Independent researcher: Tegeler Str. 9, 38518 Gifhorn, Germany \\ ${ }^{4}$ Lower Saxony State Service of Cultural Heritage, 30175 Hanover, Germany
}

Correspondence: Inke E. M. Achterberg (iachter@gwdg.de)

Received: 9 January 2017 - Discussion started: 10 March 2017

Revised: 30 July 2017 - Accepted: 16 August 2017 - Published: 25 January 2018

\begin{abstract}
The investigated northwest German mire site at "Totes Moor" is densely covered with subfossil pine stumps (Pinus sylvestris L.) from the fen-bog transition. This facilitates the spatio-temporal reconstruction of mire development, which is based on 212 in situ tree stumps in the case study presented here. Six dendrochronologically dated site chronologies together cover 2345 years between 6703 and 3403 BC. The gaps in between are 6 to 550 years long. Additionally, a floating chronology of 309 years, containing 30 trees, was radiocarbon-dated to the beginning of the 7 th millennium cal BC. Peat-stratigraphical survey was carried out additionally, and elevations a.s.l. were determined at several locations.

Tree dying-off phases, which indicate water level rise at the site, mostly in context of the local fen-bog transition, are evident for ca. 6600-6450, ca. 6350-5750, ca. 5300-4900, ca. 4700-4550, ca. 3900-3850, ca. 3700-3600, ca. 35003450 and ca. $3400 \mathrm{BC}$. The spatial distribution of the dated in situ trees illustrates the phase-wise expansion of raised bog over fen peat at the site. The documented bog expansion pulses likely correspond to climatic wet sifts.
\end{abstract}

\section{Introduction}

Raised bog development shaped the northwest German lowland during the Holocene, as eventually about a third of the area had been covered by mires (fens and bogs) (Metzler,
2004). The development of these mires on the underlying nutrient-poor glacial deposits was largely determined by climatic variations (Ellenberg, 1996). The area was particularly characterized by large lowland raised bogs, which grow better under humid and cool conditions (Behre, 2008). The expansion of these raised bogs is evident since the 7 th millennium BC, with a strong increase between 5100 and 3600 BC (Eckstein et al., 2011; Petzelberger et al., 1999). The peat in the area contains a valuable environmental record of the past millennia.

The raised bogs were treeless in their central parts, while most of the surrounding region was wooded. Even the fens were wooded in large parts, often forming alder (Alnus) swamp forests or carrying other tree species. Often at the margins of a raised bog a swamp (lagg) develops, fed by runoff water from the bog mixing with ground water. In contrast to the otherwise generally treeless raised bog (Ellenberg, 1996), the more drained margin of the raised bog towards the lagg, is commonly wooded by pine (Pinus sylvestris L.). The expansion of the raised bogs (which can be expected to occur during moist periods) often causes severe growth conditions for bog trees and consequently widespread dying-off phases. The remains of the affected trees are preserved under Sphagnum peat in the process. Stratigraphically the pine stumps mostly mark the local fen-bog transition. When in situ stumps are dated, they document the raised bog expansion. 


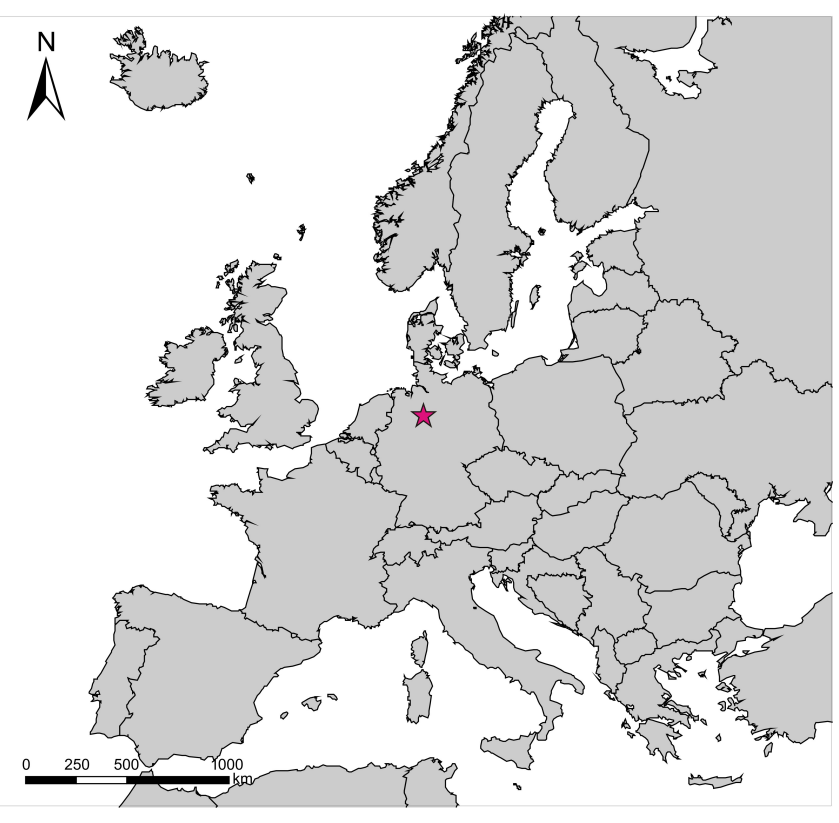

Figure 1. Location of the study site TOMO_south, indicated by a star.

Due to peat mining and the uncovering of such stump layers, areal dendrochronological investigation became possible. The trees dated absolutely by dendrochronology deliver the finest temporal reconstruction of bog expansion and local bog formation, particularly by their dying-off dates (Eckstein et al., 2009, 2010; Edvardsson et al., 2014, 2016; Krąpiec et al., 2016; Leuschner et al., 2002, 2007). Eckstein et al. (2009, 2010, 2011) have shown that the tree dying-off occurs in phases, which are often synchronous in different mires. They were able to show that the tree dying-off is mostly due to hydrological changes, while fire and storm have been found to be of little relevance on the investigated sites. Particularly the observed synchrony of pine establishment and dying-off phases in different mires shows that the local mire development documented by the trees is strongly linked to climatic variations (Eckstein et al., 2009, 2010, 2011; Edvardsson et al., 2012a, b).

The phase-wise advance of a raised bog in northwest Germany is particularly well documented in the mire "Totes Moor" at the site TOMO_south (Fig. 1). At the site, tree remains from one stratigraphical stump-layer (Fig. 2) turned out to originate from four millennia, documenting the bog progress across some $500 \mathrm{~m}$.

At site TOMO_south, the spatial as well as the temporal distribution of many preserved trees has been obtained. The present study aims to connect areal changes to the temporal patterns observed.

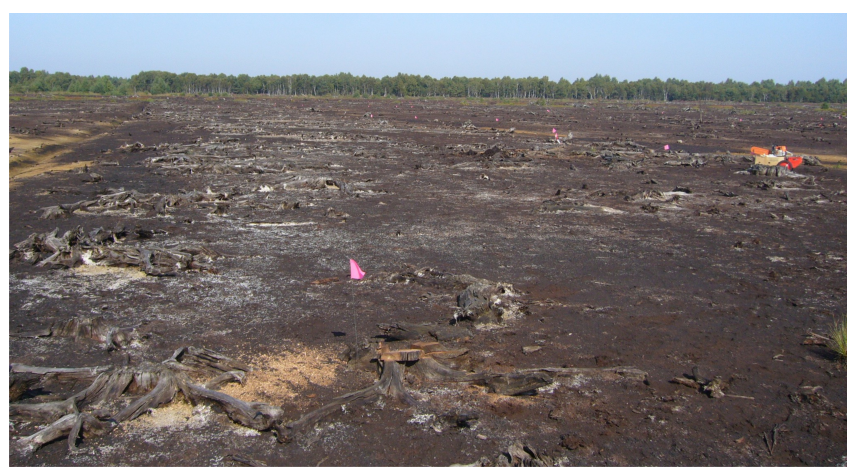

Figure 2. View of site TOMO_south. The upper layers of peat have been removed. Numerous tree stumps are protruding. Photo: Inke Achterberg.

\section{Material and methods}

The Totes Moor mire complex is located north of the Steinhuder Meer, a lake near Hanover. The undulating relief below the mire consists of sand and is likely to have held several small ponds and isolated mires before the expanding mire complex connected them. The whole depression of the lake is based on the same nutrient-poor glaciofluvial deposits (mostly sand) that characterize the geest region.

On the site TOMO_south many in situ tree stumps as well as in situ stems and ex situ stumps (pulled during ditch digging and left at the ditch side) were sampled as radial slices using a chainsaw. The tree remains were documented by using a feature table (regarding their growth, size, conservation condition etc.), photographic pictures and GPS coordinates. On some tree stumps, the root depth and shape were investigated. Later, the samples were dried, reduced by circular saw, and frozen. Then, suitable measuring radii were surface-cut by scalpel, contrasted by rubbed-in chalk dust and measured on an Aniol motorized measuring device with CATRAS measuring software to a precision of $0.01 \mathrm{~mm}$. The tree-ringwidth series were cross-dated using mainly the V-program set (EXTRACT, HEADER, SUMMORY, SYNCH2, VFORMAT, vshow, VSORT) by Thomas Riemer (Riemer, 1994, and unpublished work) and the TSAPWin program by Rinntech (Rinn, 2003). The Lower Saxony chronologies of oak and pine were used as a base for dating. Part of the Lower Saxony Pine Chronology is also a product of this work. For the floating chronology segment three radiocarbon dates, which were determined at the Leibniz Institute for Applied Geophysics (LIAG) in Hanover, were wiggle-matched on the base of the IntCal13 calibration curve (Reimer et al., 2013) using the OxCal 4.2 online software (Bronk Ramsey et al., 2001; Bronk Ramsey, 2009).

In situ finds were later separated from ex situ finds. For the spatio-temporal reconstruction of raised bog development (Fig. 5), stumps with root plates partially dragged upward, which retained part of their root system within the grown peat 


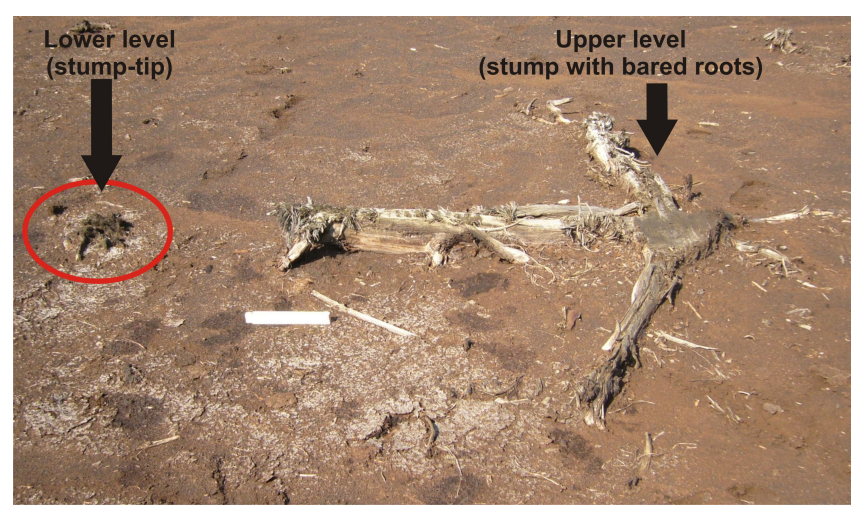

Figure 3. Tree stumps at site TOMO_south grown on two elevation levels. The upper level trees are sometimes supported by their dead successors. Photo: Inke Achterberg.

and thus their location, were used along with the finds that were in situ in the stricter sense. Up to 96 trees have possibly been moved in such a way. They were added to the 116 trees which were considered "in situ" in a stricter sense. In total 210 tree stumps with dendrochronological datings and 2 radiocarbon-dated tree stumps are included in the reconstruction and displayed (Figs. 5 and 6). All 212 are referred to as "in situ" in the following. All maps were created using ArcGIS 9 and 10 (Esri) mapping software. Figures were prepared using CoralDRAW software.

In addition, the peat stratigraphy of 56 cores at the site was investigated macroscopically. Elevations a.s.l. were determined by stadia survey for 36 of the peat cores taken for this study, and for 63 on behalf of ASB-Humus peat mining company, who kindly shared their data. The elevation a.s.l. of the mineral base (sand) beneath the peat is depicted as a regularized spline interpolation on the base of the total 99 elevation measurements (Fig. 6).

Dendrochronological dates are given in years BC and radiocarbon dates in years cal BC. Labelled time spans, like chronology segments or gaps, always include the years named.

\section{Results}

At the site TOMO_south, a rather levelled field left by peat mining revealed the remains of an apparent pine forest (Fig. 2). A closer look revealed that what had appeared to be one continuous tree layer actually did contain neighbouring stumps grown on slightly different elevation levels (Fig. 3).

Of the 700 tree stumps sampled at this site most were pine (Pinus sylvestris), only 10 oak (Quercus sp.) stumps were sighted and sampled. The pine remains often had retained bark in the lower parts, often being preserved to bark edge or showing only minimal decay at the outermost rings.

\subsection{Temporal distribution of the trees}

Only after many pine stumps had been sampled (a first sampling of about 70 trees did not provide good crossdating results) was dendrochronological dating successful for 477 trees. An additional floating chronology segment of 30 trees was radiocarbon-dated. The trees at the seemingly homogeneous site in fact originated from various centuries (Fig. 4, Table 1). They grew around $7000 \pm 80$ to $6700 \pm 80 \mathrm{cal} \mathrm{BC}$ (floating chronology segment, wigglematched C14 date) and between 6703 and 3403 BC (dendrochronological calendar dates). The floating chronology segment covers 309 years, while the chronology segments with dendrochronological calendar dates cover 2345 years.

The majority of the trees (443) originate from the 7th to 5th millennia BC. Much fewer trees (34) represent the 4th millennium BC. Tree occurrence was not scattered over time but is found to cluster in at least eight groups (chronology segments C14 and A1-F, Fig. 4). There are also periods without pine trees preserved at the site: while the two shortest of the five gaps between the site chronologies ( 6 and 11 years in length) belong to the poorly replicated 4 th millennium BC and are likely due to sampling design (which, in this case, is the placing of the site borderline through peat mining), the longer gaps between the well-replicated chronologies likely reflect the actual dynamic at the site.

There are periods where tree establishment and tree dyingoff events appear rather scattered (e.g. 6000-5800 or 5230$5120 \mathrm{BC}$ ), and intervals where the wooded phases display rather clustered tree establishment and tree dying-off. Particularly clear are the dying-off events around 6315, 5060 and 3838 BC (Fig. 4).

Rejuvenation pulses, where several trees germinate within a few years, are found within several segments. This can be seen clearly in segments C14, A2 (repeatedly) and B. Segments $\mathrm{C}$ and $\mathrm{E}$ depict the same, but less clearly. Segment $\mathrm{F}$, consisting of only five trees, is too poorly replicated to evaluate patterns. Segment A1 does not show the described pattern. Neither does segment $\mathrm{D}$, but it is also poorly replicated, consisting of only 10 trees. A closer look reveals that all rejuvenation pulses within segments are preceded by a time of limited or even missing rejuvenation. The rejuvenation pulses hence seem to mark the end of periods with limited tree establishment. In several cases the phases of limited tree establishment are also phases of frequent tree dying-off. This is particularly clear for the germination pulse beginning with the dying-off event around $6315 \mathrm{BC}$.

\subsection{Reconstructed bog expansion}

Mapping of the dated in situ trees generally shows groups of contemporaneous trees growing together. The oldest trees, from the early 7th millennium BC, cluster in the south-east of the plot, while the youngest, those of the 4th millennium BC, are found to the north-west, with the rest arranged in be- 


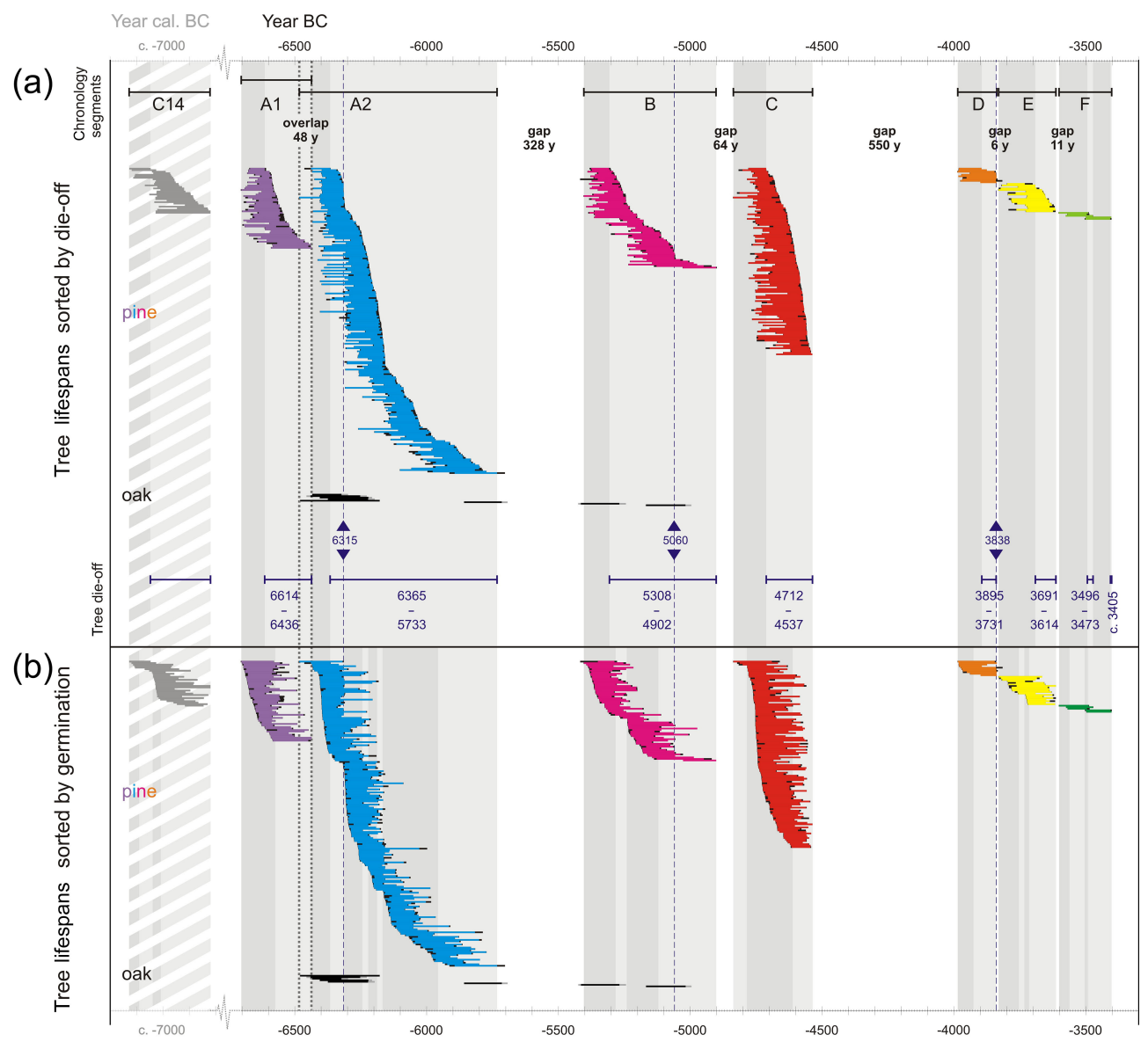

Figure 4. Temporal distribution of pine trees at site TOMO_south. On top the chronology segments C14 and A1-F are indicated. The gaps between the site chronology segments (white) are labelled with their duration. The time covered by the site chronologies of TOMO_south is underlain in grey, and that for the floating chronology segment C14 striped in grey-white. The coloured horizontal lines indicate the lifespans of the individual dated trees from the site (measured rings coloured, estimated missing rings black). The trees of each chronology segment (Table 1) are shown in a different colour (A1: dark violet; A2: blue; B: pink; C: red; D: orange; E: yellow; F: green), the floating chronology segment $\mathrm{C} 14$ in grey. The colours are used accordingly in the spatial mapping (Figs. 5 and 6). The oaks from the site are displayed in black, below the pines. In (a) the trees are sorted by dying-off date. The three most prominent events of cumulative tree dying-off are highlighted by a dashed blue vertical line and labelled by year BC. Below, the periods from first to last tree dying-off (last measured ring) are indicated, labelled by years BC. The lighter grey backgrounds indicate when the trees of a chronology segment start to die off. In (b) the trees are sorted by germination date. Here, the lighter grey backgrounds indicate periods with limited tree establishment.

tween. This clearly shows the general direction of raised bog expansion from south-west to north-east across the plot, even though there are some discontinuities within the site. Firstly, the groups of trees are not arranged in orderly stripes (Fig. 5) but form tongues and islands, often in correspondence to the dynamics of the mineral base (sand) beneath (Fig. 6). On sandy elevations trees persisted much longer, while the surrounding mire had long become a treeless raised bog (Fig. 7). Secondly, there are sometimes individual trees from one time interspersed into a group from another.

The mineral base is lowest to the south-east, where the oldest trees were found. Those trees document the oldest part of raised bog in the plot.
In Fig. 5 the raised bog advance has been reconstructed according to the dated in situ tree remains. The interpolated areas (Fig. 5) were set in a "no tree growth after" approach. That is, in places where trees from different chronology segments occur intertwined, the place was assigned to the younger specimen.

This was done in an attempt to depict the advance of the raised bog, which, in its final state, is mostly treeless (Ellenberg, 1996).

\subsection{Peat stratigraphy}

The peat stratigraphy is shown for 31 cores of the site (Fig. 8), displayed in elevational relation. In total, elevation a.s.l. has been determined for 36 of the 56 cores which were 


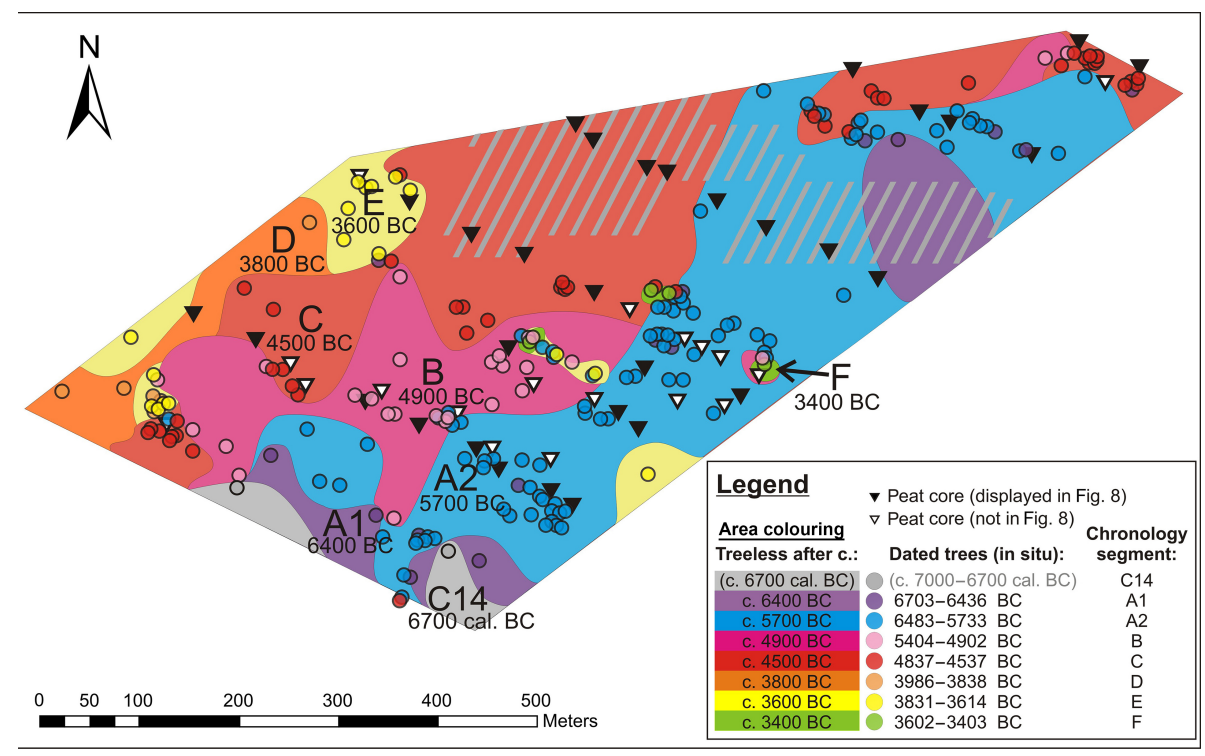

Figure 5. Reconstructed raised bog advance in terms of "no more tree growth". The coloured dots indicate in situ tree remains, while their colour indicates the chronology segments they belong to. The hachures indicate areas with a lack of dated in situ samples. The coloured areas show where no more trees grew at a certain period. In this sense, the oldest section is where only trees of the floating, radiocarbon-dated segment $\mathrm{C} 14$ (beginning of the 7th millennium cal BC) were found, which is coloured grey. The dark violet areas show where no trees younger than the first group of trees with dendrochronological calendar dates, A1 (early 7th millennium BC), were found. Blue areas feature only trees from the late 7th and early 6th millennium BC (A2) and older. The pink area delivered trees from the second half of the 6th millennium BC and the beginning of the 5th (B). The red area shows where no trees grew after the first half of the 5th millennium BC (C). The orange indicates where, after that, only trees from 4000-3800 BC (D) were found. The yellow area still featured trees in the first half of the 4th millennium BC (E), and the green in the second half of the 4th millennium BC (F). The colours with the corresponding dates are given to the right.

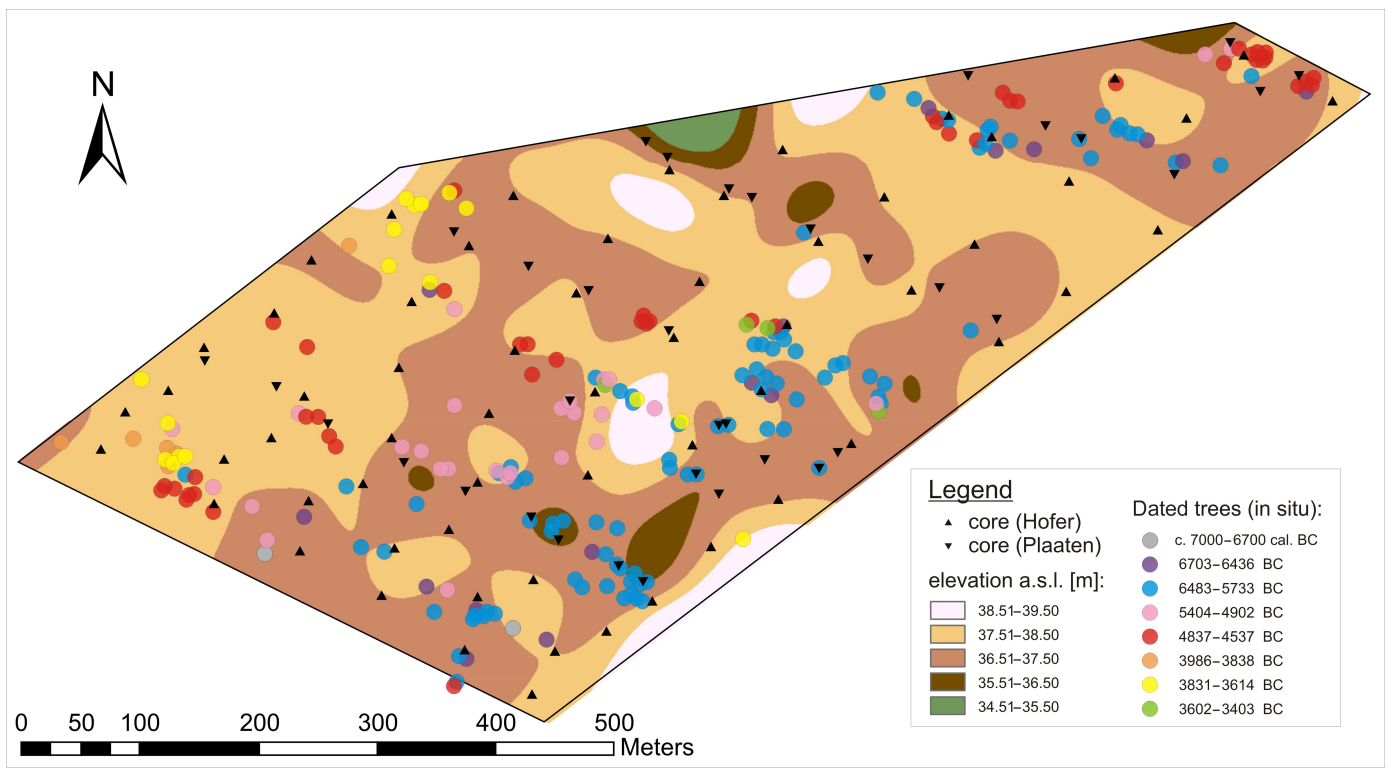

Figure 6. Elevations a.s.l. of the mineral base (sand) below the peat. Regularized spline interpolation of 99 measurements. The elevations are interpolated using a regularized spline. The actual measurements range from 36.42 to $38.16 \mathrm{~m}$ a.s.1.; therefore, the first and the last elevation class (green, below $35.50 \mathrm{~m}$ a.s.1., and white, above $38.51 \mathrm{~m}$ a.s.1.) are products of extrapolation only. The coring points are indicated by triangles. The dated in situ trees are shown as circles, for each chronology segment (Table 1) in a different colour (C14: grey; A1: dark violet; A2: blue; B: pink; C: red; D: orange; E: yellow; F: green). 
Table 1. Chronology cover. For this table, only the measured rings were used, and estimations of missing rings to pith or bark were not added. Only the trees with dendrochronological calendar dates are listed below.

\begin{tabular}{|c|c|c|c|c|c|c|c|c|}
\hline \multirow{2}{*}{$\begin{array}{l}\text { Chronology } \\
\text { segment } \\
\text { name }\end{array}$} & \multicolumn{2}{|c|}{$\mathrm{A}$} & \multirow[t]{2}{*}{ B } & \multirow[t]{2}{*}{$\mathrm{C}$} & \multirow[t]{2}{*}{$\mathrm{D}$} & \multirow[t]{2}{*}{$\mathrm{E}$} & \multirow[t]{2}{*}{$\mathrm{F}$} & \multirow[t]{2}{*}{ total } \\
\hline & A1 & A2 & & & & & & \\
\hline Colour & Dark violet & Blue & Pink & Red & Orange & Yellow & Green & \\
\hline $\begin{array}{l}\text { Chronology } \\
\text { cover } \\
\text { (yr BC) }\end{array}$ & $\begin{array}{r}6703 \\
6703-6436\end{array}$ & $\begin{array}{l}5733 \\
6483-5733\end{array}$ & $5404-4902$ & $4837-4537$ & $3986-3838$ & $3831-3614$ & $3602-3403$ & $\begin{array}{l}\text { Dispersed } \\
\text { over } \\
3301 \text { years }\end{array}$ \\
\hline $\begin{array}{l}\text { Tree dying- } \\
\text { off (yr BC) }\end{array}$ & $6614-6436$ & $6365-5733$ & $5308-4902$ & $4712-4537$ & $3895-3838$ & $3691-3614$ & $\begin{array}{l}3496-3473 \\
3407-3403\end{array}$ & 1482 years \\
\hline $\begin{array}{l}\text { Chronology } \\
\text { segment } \\
\text { length (years) }\end{array}$ & 268 & 752 & 504 & 301 & 149 & 218 & 202 & 2345 years \\
\hline $\begin{array}{l}\text { Chronology gap } \\
\text { after (years) }\end{array}$ & - & 328 & 64 & 550 & 6 & 11 & - & 959 years \\
\hline Replication (trees) & \multicolumn{2}{|c|}{254} & 66 & 123 & 10 & 19 & 5 & 477 trees \\
\hline
\end{tabular}

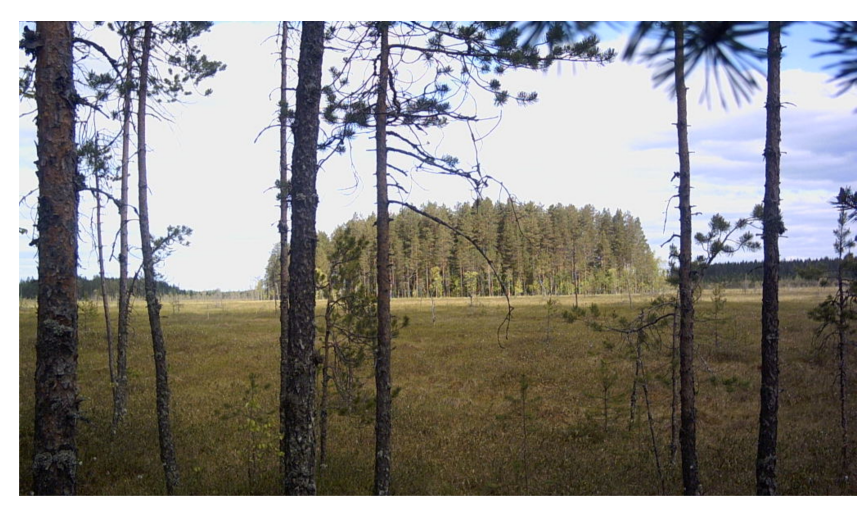

Figure 7. Pine growth at a bog site in Finland. View across a stretch of treeless bog. In front are small trees, thinning out where the peat deepens. In the back large trees form a wooded "island" where the mineral ground ascends. Photo: Inke Achterberg.

peat-stratigraphically investigated at the site. Please note that some cores have been taken at the edge of the peat excavation field, where peat was left standing more than $1.5 \mathrm{~m}$ higher than the level of the tree stump layer.

The general order above the glacial sand deposits is the following: brown moss peat on bottom, wood-rich peat above, followed by Sphagnum peat on top. The pine tree remains are found at the fen-bog transition. This picture is rather continuous over the site, with differences mostly restricted to layer thickness. The brown moss peat is mostly weakly humified, often featuring Menyanthes seeds
(Menyanthes trifoliata) in the middle or upper part and silt near the bottom.

The wood-rich peat varies, mostly being more strongly humified, but containing various portions of Betula (bark), Alnus (wood), Pinus (bark and cone) and charcoal in different spots and layers.

A few spots feature an Eriophorum layer (Eriophorum vaginatum) below the Sphagnum peat. More cores show some Eriophorum mixed in with the lower Sphagnum peat or the upper wood-rich peat.

The Sphagnum peat, where distinguishable, consists of Sphagnum section Acutifolia peat, Sphagnum section Cuspidata peat and Sphagnum-Carex peat.

A few of the cores (two of the ones shown) feature highly humified fen peat in the lower part, which is likely to be brown moss peat in a decomposed state. In agreement with this assumption, the brown moss peat of most cores is more humified at its base.

\subsection{Root morphology}

There is one main feature dividing the pines into two groups by their roots: the first type of root systems (type 1) spreads out horizontally, without any downward pointing roots. The central root at these trees has either died off at a length of about $10 \mathrm{~cm}$ or less or is not traceable at all. The second type of root systems (type 2), however, displays downward growing roots, most of them with a pronounced central root that has grown vertically downwards. Most often, these reach 20 to $40 \mathrm{~cm}$ below the root plate. 

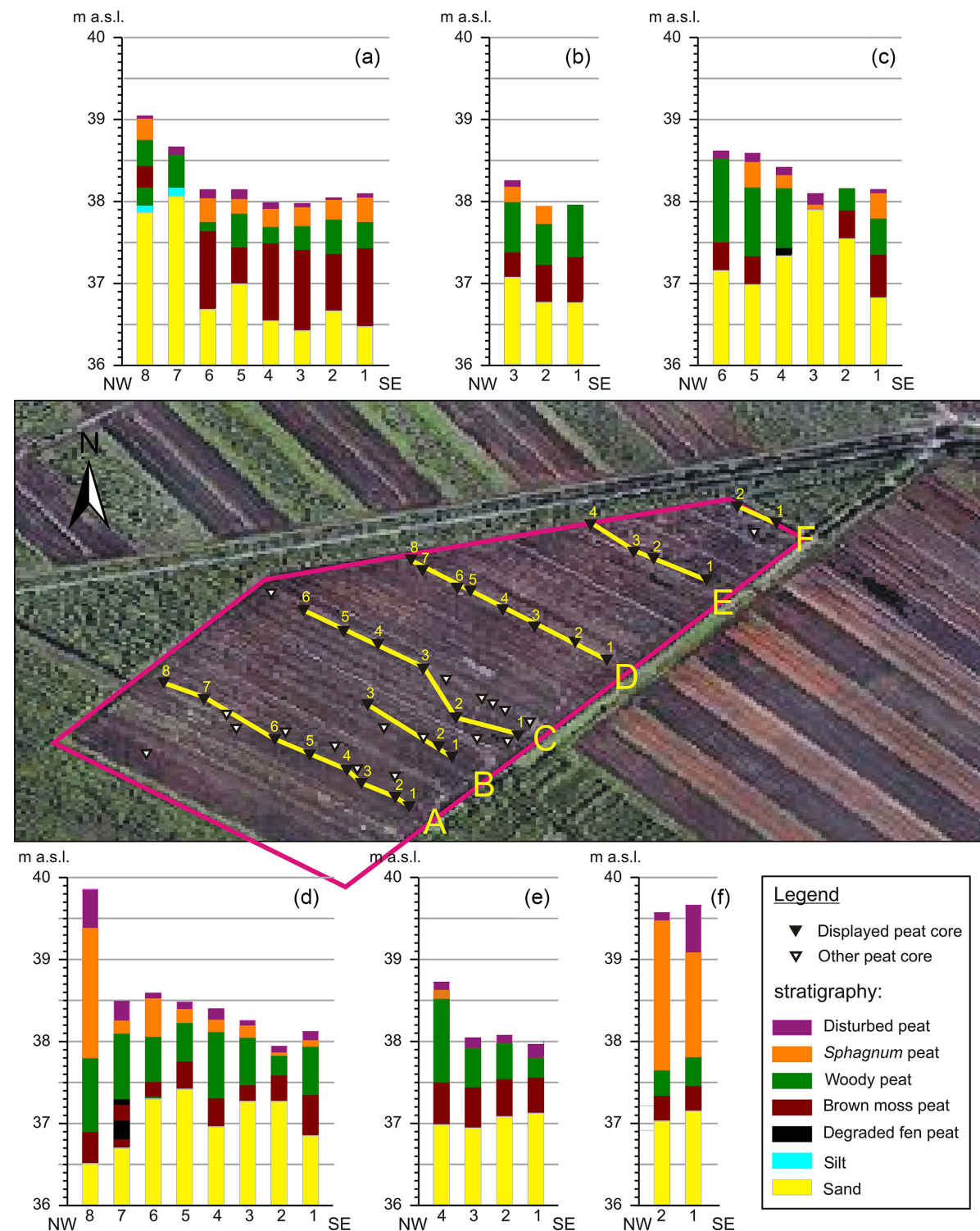

Figure 8. Peat stratigraphy. Six transects are shown with the peat stratigraphy and elevation a.s.l. of the cores. In the aerial view, site TOMO_south is outlined in pink. The locations of the displayed peat cores are indicated by black triangles, yellow lines connecting the transects. Peat stratigraphy for cores without elevation measurement is not shown. Please note that cores D8, F1 and F2 were taken at the border to the plot, where peat was left standing significantly higher than within the plot, where the tree layer was exposed. Underlying satellite image: (2008 Google Earth, image (C2009 Geo Content, (2009 Tele Atlas.

These two types clearly show up in the ex situ material pulled from the ditches. Roots below the stem were investigated also for 18 in situ stumps (Fig. 9), primarily to clarify if their roots reached the mineral soil below the peat. This was not the case with the examined specimen.

\section{Discussion}

\subsection{The preserved trees}

During dry periods, with consequently lowered bog water tables, pine forestation can temporally also occur on the bog. Such growth of large pines within raised bog (rooting in Sphagnum peat) was described by, among others, Overbeck (1954) for a mire in northern Germany, by Moir et al. (2010) for such findings in Scotland, by Edvardsson et al. (2014) in southern Sweden, or in general terms by Ellenberg (1996).

However, this is not the case at TOMO_south, where the pines occur at the fen-bog transition and not within Sphagnum peat layers. As confirmed by peat stratigraphy, the tree remains in TOMO_south represent a persistent pine forestation at the raised bog margin. Pine forestation at raised bog 


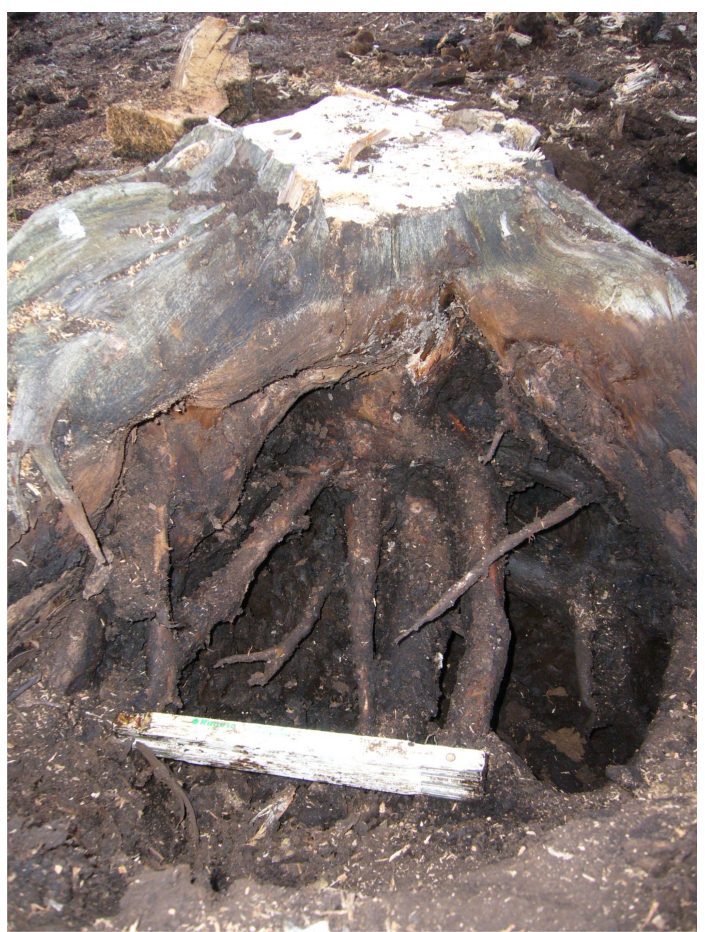

Figure 9. Strong downward roots below a tree stump at TOMO_south (tree life 5396-5230 BC, chronology segment B). Photo: Inke Achterberg.

margins is a very typical occurrence. The pines colonize marginal parts of the bog, where the ascending bog surface is well drained compared to more central parts (Ellenberg, 1996; Overbeck, 1975).

The death and conservation of the trees, however, appears to be closely connected to the expansion of the raised bog and the rise of the corresponding water table. This has been found evident on base of abundant upward growing roots late in the tree's life, the drastically narrowing rings near the bark, peat stratigraphical context and the state of conservation at various comparable sites investigated in northwest Germany and southern Sweden (Eckstein et al., 2009, 2010; Edvardsson et al., 2012b, 2014; Leuschner et al., 2002, 2007). Therefore the death of the trees and their conservation under Sphagnum peat dates raised bog expansion, and using in situ stumps adds location to the event. As the site is densely covered with tree stumps (rather throughout), we assume that all significant and lasting raised bog expansion should be documented by embedded trees.

The tree data display phases of cumulative dying-off on the one hand and gaps between site chronologies on the other. This documents phases of the bog expanding, and phases without significant expansion at the site.

The phases of bog expansion should generally relate to relatively humid climate phases, as the bogs are dependent on rainwater (Ellenberg, 1996). Raised bog formation can be favoured by a preceding lowering of the water table through

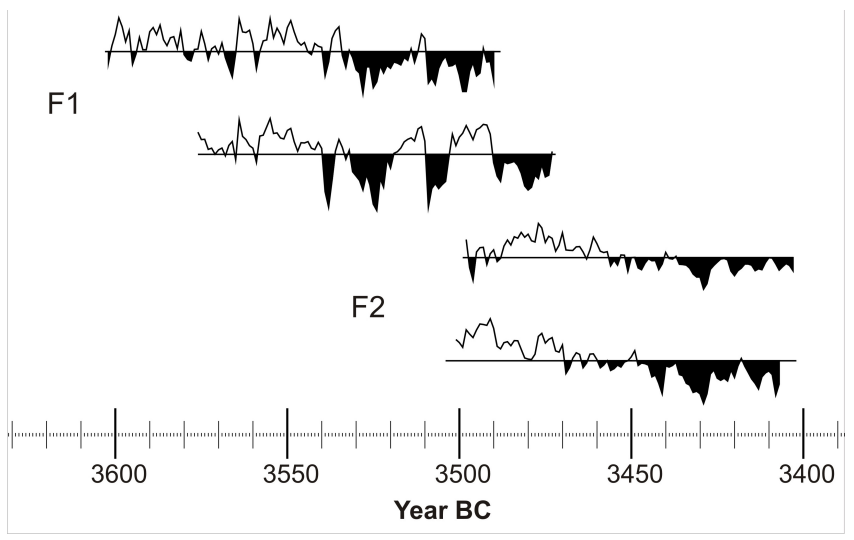

Figure 10. Tree-ring-width curves of chronology segment F. The mean value of the tree ring widths is indicated by a horizontal line for each curve; the area below mean is filled black to highlight growth depressions. One sample is not shown because it is missing several rings to bark and therefore the record of the final years of that tree's life. All trees show narrow ring widths prior to their deaths. These growth depressions are not reflected equally in the surviving trees. This illustrates the locality of the calamity.

the disconnection of the fen peat surface from the lowered ground water and its nutrient supply (Hughes, 2004; Tahvanainen, 2011; von Bülow, 1935). At site TOMO_south this combination of a drier phase with lowered water tables followed by a phase of swift raised bog expansion may have occurred repeatedly. A lowered water table is documented by numerous tree stumps with vertical roots (type 2). These roots often reach 20 to $40 \mathrm{~cm}$ below the root plate, and include a thick central root going straight down (Fig. 9). Root system type 1, however, being spread out flat and without any pronounced vertical root, is also common at the site. Such roots indicate a higher water table, limiting rooting space at the time of growth. This shows that not all of the trees embedded by the expanding raised bog grew under drier conditions with significantly lowered water tables.

In general, tree growth on a mire can also contribute to a lower water table, as transpiration is being increased (Moir et al., 2010; Limpens et al. 2014). This effect can be reversed, however, where shading in high-density stands reduces evaporation even more and thus results in increased surface wetness (Limpens et al., 2014).

The area around the bog appears to have been wooded continuously, as pollen records from the bog itself (Shumilovskikh et al., 2015; Schlütz unpublished) and the regional landscape history (Behre, 2008) suggest. The trees from these surrounding mineral soils would not be preserved, however.

\subsection{Dying-off phases}

Most indicative for periods of lateral bog growth are those of tree dying-off. As there are seven dendrochronologically 
dated chronology segments, there are at least seven such periods (Fig. 4). Particularly for the chronology segments A2 and $\mathrm{B}$, phases of accelerated and decelerated bog advance appear to be depicted in the trees. Even though this could partially also relate to the irregular sampling pattern, some prominent short-term events of cumulative tree dying-off, like those around 6315,5060 and $3838 \mathrm{BC}$, are clear. The periods in which the trees died off are 6614-6436, 6365-5733, 53084902, 4712-4537, 3895-3838, 3691-3614, 3496-3473 and 3407-3403 BC (Fig. 4, Table 1). These are interpreted as phases of raised bog expansion, which in turn imply moist phases. How the trees are successively affected by the local raised bog development is also illustrated in the individual tree ring series, as shown for segment $\mathrm{F}$ (Fig. 10).

The floating chronology segment $\mathrm{C} 14$ shows subsequent dying-off approximately. The trees of segment C14 are less well preserved. This might indicate a mire environment at the time with higher microbial activity, possibly with less continuous water logging of the mire surface.

\subsection{Rejuvenation pulses and suppression}

The rejuvenation discussed here is limited to trees which grew up to form a number of rings sufficient for dendrochronological dating.

In the course of dying-off phases, rejuvenation is often missing. When all trees of stand are killed by a fatal influence, young trees germinated shortly prior to the event would not occur in the dendrochronological record due to insufficient tree ring numbers for dating. This can not be more than part of an explanation, however, since the dying-off phases are in many cases stretched longer than the lengths of time required of a tree ring sequence for dating.

The moist conditions relating to the dying-off phases, however, would likely also suppress successful tree establishment. Holmgren et al. (2015) found Pinus sylvestris recruitment on bogs to be more successful on drier sites (hummocks) with lower water tables. They found natural seedling establishment to occur on both moist (lawns) and drier microsites (hummocks) equally. Young trees, however, were much less abundant on the moister sites (lawns), and adult trees were only found on the drier sites (hummocks) with lower water tables (Holmgren et al., 2015).

Several times in the record, numerous germinations occur synchronous. These are mostly found following a phase (mostly of one to a few decades) of suppressed rejuvenation. Hence, they most likely mark the end of the unfavourable conditions which suppressed rejuvenation. Drier conditions on the peat surface are likely a factor. Furthermore, the large numbers of simultaneous seedling establishment can be explained by the lack of shading undergrowth as a preceding generation of young trees is missing.

Tree rejuvenation events (germination phases), which took place simultaneously in several different peat bogs, sometimes coincide with dying-off events, and more often fol- low directly after them. Eckstein et al. (2010, 2012) and Leuschner et al. (2007) have referred to this as germinationdying-off phases (GDOs). Even though a spatial pilot study (Stenzel, 2013) did not find the newly established trees directly in the area shaded by those trees which had just died off, the mechanism causing the coherence is still suspected to be driven by competition for light. Other trees and shrub (e.g. Betula or young pine trees) would have suffered from the same influence which killed the large pine trees and thereby created an opening in the canopy. This could explain the coherence or close succession of dying-off and germination phases.

Zackrisson et al. (1995) also take seed production into account to explain rejuvenation pulses in pine populations. Conditions stressful to the trees can enhance seed production. However, favourable climate conditions may also influence seed production. Enhanced seed production under stressful conditions supports rejuvenation when the older tree generation is about to die off. The germination and establishment of these seedlings, however, depends on the opening of canopy created by the tree dying-off, and on otherwise suitable conditions at the site. Therefore, it is unclear how far seed production might be reflected in tree establishment at the given site.

\subsection{Chronology gaps}

The site chronologies of TOMO_south are interrupted by five gaps, ranging between 550 and 6 years in length (Table 1).

The two very short gaps ( 6 and 11 years respectively) are rather insignificant, especially since the respective period is not well replicated. These gaps are likely to result from sampling design, as the neighbouring chronology segments are poorly replicated and the according trees are found on the rim of the investigated area. It is well possible that more trees represent that period but that they were located just outside the margin of the site to the north-west. Both short gaps are from the 4th millennium BC (3837-3832 (6 years) and 46133603 BC (11 years)) (Table 1), when trees only grew at the site on sandy elevations, forming wooded "islands" in the mire (Figs. 5, 6 and 7).

The three longer gaps are more meaningful. The two very long gaps are 5732-5405 (328 years) and 4536-3987 BC (550 years), the gap of intermediate length (64 years) is 4901-4836 BC. All three are framed by well-replicated site chronology segments, with the respective trees found well within the site. Given the dense sampling of the site, it can be assumed that the large gaps actually represent periods with no or very few pine trees being embedded at the site.

Other studies have attributed chronology gaps in raised bogs to a lack of tree growth due to high surface wetness. This makes much sense for the tree layers well within Sphagnum peat as described, for example, in Scotland (Moir et al., 2010) and south Sweden (Edvardsson et al., 2014). At those 
sites, tree growth was only possible on the raised bog during drier phases.

In the case of the present study, however, the stratigraphic position of the tree layer is at the fen-bog transition. Apparently, at TOMO_south the expanding raised bog embedded trees grown at its rim. The site was thoroughly covered with pine stumps. These were representatively sampled and dated. Taken together, this suggests that the large chronology gaps at TOMO_south represent periods of (near) stagnation of the lateral raised bog growth. Therefore the gaps are not interpreted as periods of particularly high surface wetness in this case but instead the reverse. Instead, during the periods of site chronology gaps the raised bog at TOMO_south appears not to have expanded significantly. Lacking bog expansion can be related to relatively dry phases. There are, however, tree dying-off phases documented at other bogs in northwest Germany within the time of these gaps. In particular, in the 550-year gap at TOMO_south (4536-3987 BC), there are two pronounced dying-off phases (ca. 4490-4370 and 4230-4170 BC) within and one at the end of the gap (ca. 4010-3960 BC) in other bogs (Achterberg et al., 2015). Therefore, these phases of apparent bog growth stagnation at TOMO_south can not be related to climatic dry phases directly.

\subsection{Spatial distribution}

The mapping of the dated in situ trees at the site (Fig. 5) shows the raised bog expansion from south-east to northwest. The mineral base is lowest in the south-east of the plot and highest to the south-west of the plot, as well as in the centre of the site (Fig. 6). This direction is parallel to the nearest lake shore.

There are clear spatial clusters of trees from the same periods, which usually border to patches of the preceding and following chronology segments. This is coherent with the picture of the advancing raised bog successively embedding the tree stumps.

The oldest parts (with trees only from the first chronology segments) are found to the south-east, where the mineral base is low. The trees from more recent centuries were found in places were the mineral base ascends, like the sandy elevation near the centre of the plot. Wooded islands within the raised bog apparently persisted for a long time (Figs. 5, 6 and 7). The distribution of trees from different chronology segments in the plot can mostly be related to the dynamic relief of the mineral base (Fig. 6).

At some places, however, there are also trees from different epochs interspersed (Fig. 5). In the mapping of raised bog expansion (Fig. 5) these places are assigned to the last tree dying-off they document, as the advancing central part of the bog should have been generally treeless (Ellenberg, 1996). Re-establishment of trees in places where trees had already been embedded before may have been favoured by drier conditions, or simply related to the dynamic relief, with the root plates of previous generations additionally serving as "stepping stones" for the new trees to grow on.

\subsection{Peat stratigraphy}

Thick and mostly weakly humified layers of brown moss peat were found at the bottom of TOMO_south peat cores. It was the base for extended tree growth, which then itself deposited thick layers of wood-rich peat. Where basal swamp forest peat is less humified, the brown moss can still be seen intertwined. Likewise intertwined is the first Sphagnum growth into the top layers of pine-rich peat. This depicts a succession to ombrotrophy, with one plant community creating the habitat for the next.

There are fine mineral materials found interspersed in several peat cores and layers. These may have been washed into the moss by temporary flooding or, particularly in the older deposits, also might have been blown into the mire.

\subsection{Climatic comparisons}

The following alignments were largely limited to records which have a certain precision of dating (dendrochronological, varve, etc.), are located with some level of proximity (European studies), regard the time frame covered by TOMO_south trees and also describe a hydrological signal. For the type of proxy used in the studies referred to and their location, please see Table 2. The temporal overview given in the following text is also displayed in Fig. 11a and $b$.

We interpret the dying-off phases as times of lateral mire expansion. Bog expansion again would require a certain humidity, which may be more dependent on a reduced evapotranspiration than the actual precipitation alone. This would mean the dying-off phases in the periods ca. 6600-6450, 6350-5750, 5300-4900, 4700-4550, 3900-3850, 37003600 , and $3500-3400 \mathrm{BC}$ indicate more humid phases. In turn, the gaps between the site chronologies and the periods of rather undisturbed tree growth are interpreted as phases of stagnation of lateral raised bog expansion. These may be related to climatic conditions unfavourable for mire growths, possibly involving drier periods. This would apply to the phases of ca. 6450-6350, 5750-5300, 4900-4700, 45503900, 3850-3700, and 3600-3500 BC.

As mentioned before, the dying-off phases observed at TOMO_south show much synchronism with dying-off phases observed at other mire sites in northwest Germany (Eckstein et al., 2009, 2010, 2011), which emphasizes their climatic context. In addition to the temporal placing of the TOMO_south record (terminating $3400 \mathrm{BC}$ ) and its location in the northwest German lowland, where settlements were established later than on the richer soils of the adjacent hills, this synchrony makes it appear unlikely that anthropogenic clearance activity in the catchment area might have had a detectable influence on the bog's hydrology. 


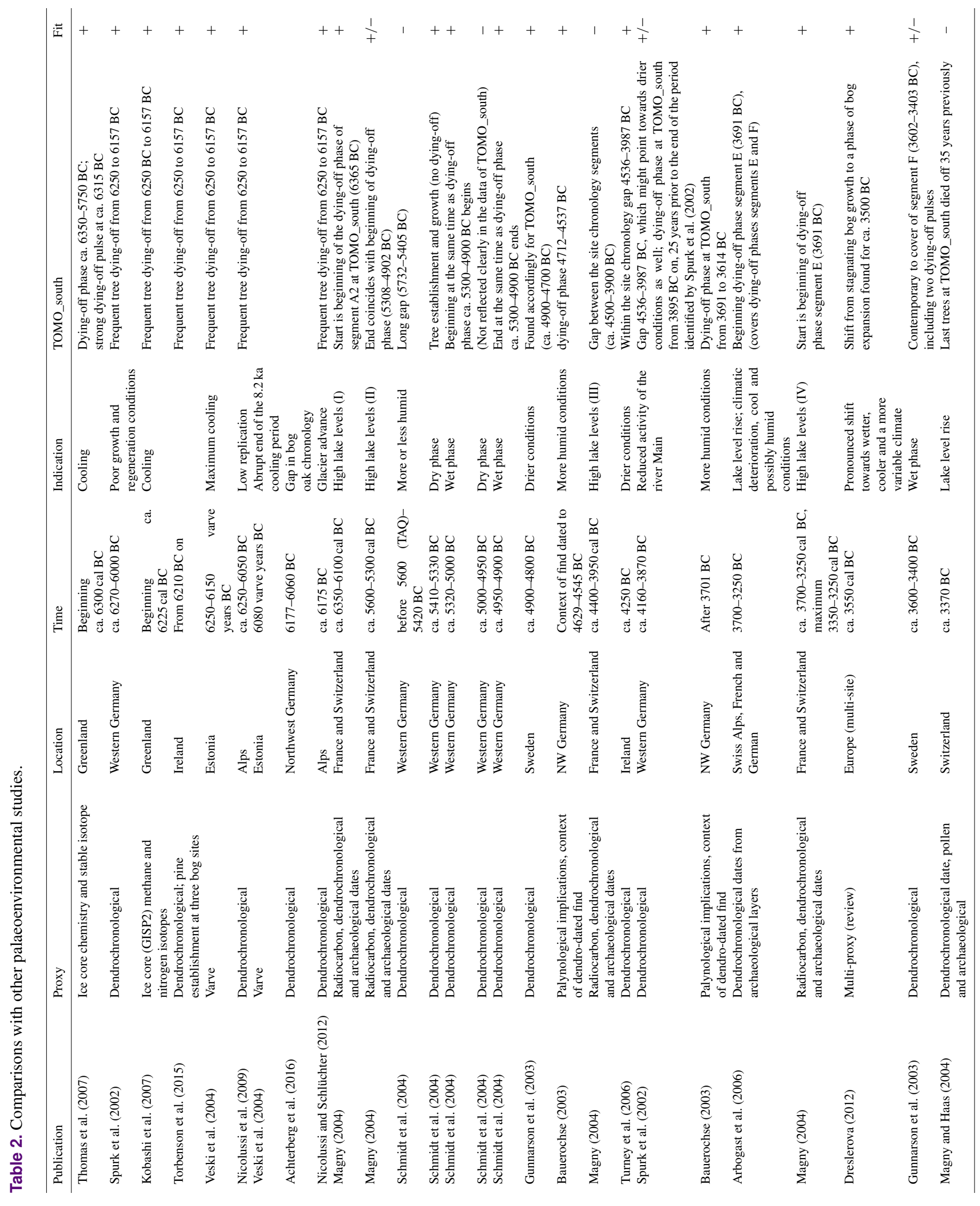



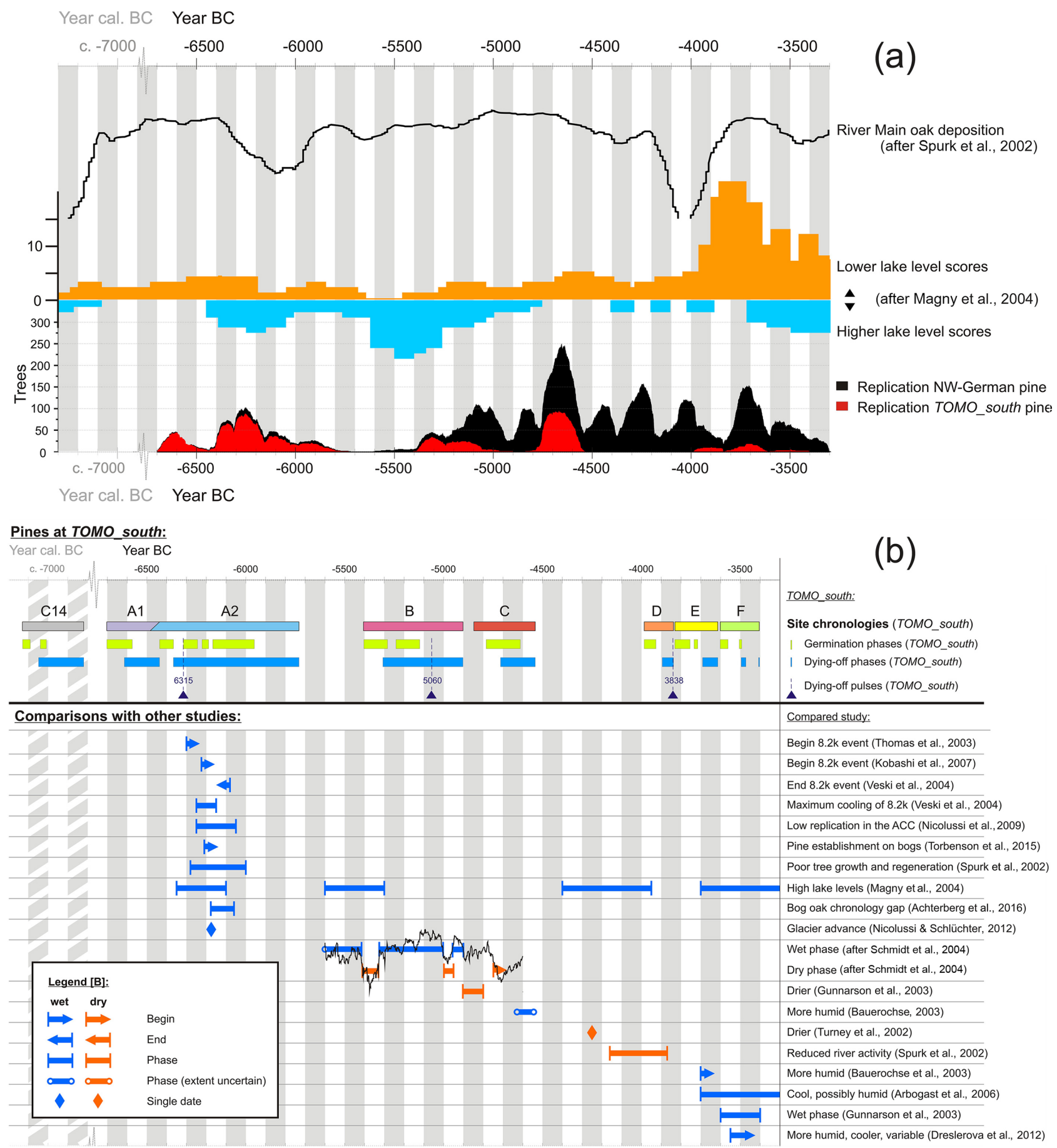

Figure 11. (a) Comparison of the replication of TOMO_south northwest German pine chronologies with other climate-related records. From top to bottom: oak deposition at the river Main (Spurk et al., 2002); scores of higher and lower lake levels in central Europe (Magny et al., 2004); replication of the northwest German pine chronology including the pines of TOMO_south, which are highlighted in red. (b) Comparison of the phases observed at TOMO_south with those of other studies.

The replication of the northwest German dendrochronological pine record, even though it is influenced by sampling patterns and the accessibility of trees depending on peat mining, also reflects climate. This shows in the European simi- larities of chronology replication (Edvardsson et al., 2016). In addition, it is also illustrated by the comparison with other climate-related records (Fig. 11a). The number of dates for lowered and raised lake levels in central Europe (Magny et 
al., 2004) displays similarities with the replication of the northwest German pine chronology. The northwest German pine declines (die-off phases visible in replication) within the long TOMO_south gap (ca. 4500-4000 BC) fit phases of higher lake levels in the data of Magny et al. (2004) particularly well (Fig. 11a). The replication at TOMO_south is largely in tune with the overall pine replication record of northwest Germany, except for northwest German phases of pine growth which are not represented at TOMO_south, dating ca. 4900-4800 and ca. 4500-4000 BC (which is a long gap between site chronologies at TOMO_south).

The $8.2 \mathrm{ka}$ event cooling phase, according to Thomas et al. (2007), began around ca. $6300 \mathrm{cal} \mathrm{BC}$. Kobashi et al. (2007) date its beginning later, to ca. $6225 \mathrm{cal} \mathrm{BC}$, while Veski et al. (2004) observe the time of maximum cooling for 6250-6150 varve years BC (Fig. 11b). Veski et al. (2004) also observe an abrupt end of the $8.2 \mathrm{ka}$ cool period for 6080 varve years BC.

Dendrochronological data in proposed context with the event include a phase of pine establishment in Irish bogs from 6210 BC on (Torbenson et al., 2015), a phase of poor growth and regeneration of west German oaks from the river Main sediments at ca. 6270-6000 BC (Spurk et al., 2002) and a gap in the bog oak chronology at 6177-6060 BC (Achterberg et al., 2016). A pronounced glacier advance at Mont Miné in the Swiss Alps was dated to ca. 6175 BC using dendrochronology (Nicolussi and Schlüchter, 2012). The replication of the Eastern Alpine Conifer Chronology (Nicolussi et al., 2009) drops after 6250 BC for about 200 years. The replication of the Northwest German Pine Chronology (Achterberg et al., 2016) is also declining at the time, but does not reach particularly low levels.

The dates mentioned above correspond well in general. Particularly good agreement is found, for example, between the beginning of the gap in the Northwest German Bog Oak Chronology at 6177 BC (Achterberg et al., 2016) and the glacier advance dated by Nicolussi and Schlüchter (2012) to ca. $6175 \mathrm{BC}$, as well as between the end of said gap in the Northwest German Bog Oak Chronology at 6060 BC (Achterberg et al., 2016) and the end of the cool phase observed by Veski et al. (2004) for 6080 varve BC. The phases of unfavourable growth conditions observed at the river Main from ca. $6270 \mathrm{BC}$ on (Spurk et al., 2002) and in the Alps from ca. 6250 BC on (Nicolussi et al., 2009) are in equally close agreement.

At site TOMO_south, a phase of frequent tree dying-off from 6250 to $6157 \mathrm{BC}$ matches the time of maximum cooling (6250-6150 varve years BC) as described by Veski et al. (2004) and the beginning of the replication decline from ca. $6250 \mathrm{BC}$ on in the Eastern Alpine Conifer Chronology (Nicolussi et al., 2009). The trees of TOMO_south display a strong dying-off pulse at ca. $6315 \mathrm{BC}$, which may relate to the event as Thomas et al. (2007) date it. However, the $8.2 \mathrm{ka}$ event does not show as clearly in the pine record of TOMO_south as it does in other records.
Magny et al. (2004) describe several phases of high lake levels in central Europe, four of which are within the time frame covered at TOMO_south (In the following these are referred to as first to fourth phase, disregarding all which are outside of the time frame discussed here.) The first of these (ca. 6350-6100 cal BC) is also within the dying-off phase of segment A2 (6365-5733 BC). The beginning of the two phases (high lake levels in Magny et al., 2004, and dyingoff at TOMO_south) are in close temporal accordance. The second phase of high lake levels, described by Magny et al. (2004) for ca. 5600-5300 cal BC, does not fit the data of TOMO_south. The onset of the event is contemporaneous to a site chronology gap at TOMO_south, which is taken to indicate dry conditions rather than wet ones, and its end is contemporaneous to the beginning of a dying-off phase at TOMO_south (segment B, 5308 BC), which should indicate the beginning of a more humid period rather than its end.

The data of Schmidt et al. (2004) seem to be in contradiction to the record of TOMO_south at that time as well. They show data from $5600 \mathrm{BC}$ on, which displays more or less humid conditions until about $5420 \mathrm{BC}$. This is within a chronology gap at TOMO_south, with the gap end (5404 BC) closely meeting the end of the relatively humid conditions observed in the data of Schmidt et al. (2004). The subsequent dry phase displayed by Schmidt et al. (2004) for ca. 54005350 BC fits the indications from TOMO_south better, where the pines begin establishment contemporary to the dry phase beginning and start dying off only after the dry phases end, in 5308 BC. The two wet phases that follow according to Schmidt et al. (2004) (ca. 5320-5000 and ca. 4950-4900 BC) fit the dying-off phase of segment B at TOMO_south (53084902 BC), which also indicates humid conditions. The beginning of the above dying-off phase is temporally close to the beginning of the first of the two mentioned wet phases, and the end of the dying-off phase is contemporary to the end of the second. This is a very close agreement of the indications of the two dendrochronological records. The interjacent dry phase (ca. 5000-4950 BC) documented by Schmidt et al. (2004) is not reflected in TOMO_south.

Gunnarson et al. (2003) describe drier conditions for ca. 4900-4800 BC. At TOMO_south a site chronology gap (4901-4838 BC) begins at the same time. The gap and the following phase of tree establishment conform to drier conditions.

More humid conditions are evident from pollen and peat data composed in the context of a trackway (Bauerochse, 2003), which is dendrochronologically dated (construction and maintenance 4629-4545 BC) (Bauerochse et al., 2012; Achterberg et al., 2015). The palaeo-botanical indications for increased humidity described by Baueroche (2003) can thus be aligned to the dying-off phase of site chronology segment C (4712-4537 BC).

The third phase of high lake levels described by Magny et al. (2004) (ca. 4400-3950 cal BC) does not coincide with indications for increased humidity at TOMO_south. It be- 
gins within a long site chronology gap (4536-3987 BC) and ends before the beginning of the next dying-off phase. There are, however, die-off phases of northwest German pines from other bogs which date to ca. 4490-4370, 42304170 and ca. 4010-3960 BC (Achterberg et al. 2015), contemporary to that phase of high lake levels described by Magny et al. (2004) for ca. 4400-3950 cal BC (Fig. 11a and b). Turney et al. (2006), on the other hand, state drier conditions for Ireland around ca. $4250 \mathrm{BC}$, also dating within the TOMO_south site chronology gap 4536-3987 BC, which is in agreement with our interpretation of the TOMO_south data.

Palynological indications for increased humidity (Bauerochse, 2003) are temporally anchored to after $3701 \mathrm{BC}$ by a dendrochronologically dated trackway (Bauerochse et al., 2012; Achterberg et al., 2015). This is within the dying-off phase of segment E at TOMO_south (3691-3614 BC), and therefore in agreement with its climatic indication. Around the same time Arbogast et al. (2006) also identify climatic deterioration, a shift towards cooler and possibly more humid conditions for ca. 3700-3250 BC. Magny et al. (2004) date the beginning of their fourth phase of high lake levels to ca. 3700 cal BC as well (ca. 3700-3250 cal BC). Despite the low replication of segment $\mathrm{E}$, these coherences make the indication of its dying-off phase appear quite valid.

The wet phase observed by Gunnarson et al. (2003) for ca. 3600-3400 BC covers about the same time as segment F. Tree die-off in segment $\mathrm{F}$ (indicating water table rise) starts later though, at ca. 3500 BC. However, both dying-off pulses of segment $\mathrm{F}$ are therefore within the wet phase documented for Sweden (Gunnarson et al., 2003), with the end of the wet phase meeting the end of the last dying-off pulse. This makes for an intermediate level of agreement.

Dreslerova (2012) points out a pronounced shift towards wetter, cooler and a more variable climate around ca. $3550 \mathrm{cal} \mathrm{BC}$, reviewing numerous European studies of climate proxy for the Holocene. The TOMO_south dyingoff phase 3496-3473 BC (segment F) may well relate to this event, which Dreslerova (2012) describes to be the beginning of a significant climatic phase.

The tree ring chronologies of TOMO_south do not cover the end of the Holocene Thermal Maximum, which occurred around ca. $2350 \mathrm{cal} \mathrm{BC}$ with a shift to cooler conditions (Seppä et al., 2005).

The trees of TOMO_south record water table change at one mire. The water table changes are largely driven by precipitation in the catchment area but are also affected by evapotranspiration. This hydrological signal has a higher temporal resolution due to its local nature than an supra-regional record (such as Achterberg et al., 2015) would. Even though the climatic drivers are the same in both cases, regional variations in rainfall, for example, are smoothed out in a supraregional record at the cost of precision, which would in turn be retained in a case study such as this.
Even though the dating of the trees and their reactions to environmental change is precise to the calendar year, that does not necessarily apply to the dating of the related climatic causes. The water table rise observed in mires can be lagged behind the climatic shifts by months or even years (Edvardsson et al., 2016).

\section{Conclusions}

The trees, stratigraphically located at the fen-bog transition, are viewed to stem from the former bog margin, being embedded by the expanding raised bogs Sphagnum peat. The tree dates document a raised bog expansion at the site for 6614-6436 (ca. 250 years), 6365-5733 (ca. 750 years), 5308-4902 (ca. 500 years), 4712-4537 (ca. 300 years), 3895-3838 (ca. 150 years), 3691-3614 (ca. 200 years), 3496-3473 (ca. 25 years) and ca. 3400 BC (4 years). These phases of lateral raised bog growth likely occurred in periods of rather humid climate.

The shorter gaps between the later site chronologies are viewed as insignificant, since they belong to poorly replicated periods documented at the site's margin. The three longer gaps between the earlier site chronology segments, however, are framed by well-replicated sections represented in the central area of the site. These are interpreted to represent periods without significant (and lasting) raised bog advance, since the site is throughout covered with stumps and these were densely sampled. These chronology gaps relating to phases of apparent bog stagnation are 57335308 (328 years), 4902-4712 (64 years) and 4537-3895 BC (550 years). There are, however, dying-off phases recorded at other northwest German bogs within these periods. These periods therefore do not appear to have been throughout dry phases in the region.

The distribution of the tree stumps of various ages across the site supports the picture of subsequent bog advance embedding the tree stumps. The bog expanded from the southeast towards north-west according to the dating of the trees, the direction of bog growth largely reflecting the elevation of the mineral base below the peat. Rises of the sandy ground formed wooded islands within the bog, being successively covered by Sphagnum peat with much delay.

Data availability. The corresponding datasets are available at pangaea.de (Achterberg et al., 2017): https://doi.pangaea.de/10.1594/ PANGAEA.884249, https://doi.pangaea.de/10.1594/PANGAEA. 884247, https://doi.pangaea.de/10.1594/PANGAEA.884248, https://doi.pangaea.de/10.1594/PANGAEA.884212.

Competing interests. The authors declare that they have no conflict of interest. 
Acknowledgements. Thanks goes to Torsten Struck for support and generous help in field work, Jens Will for a first language check and Kerry-Ann Williams for native speaker proofreading on short notice. We would particularly like to express our gratitude to ASB-Humus, especially Wilhelm Thuernau, for kindly allowing us to work on their peat extraction grounds, their helpful support of our research and for sharing their elevation data. Our sincerest gratitude goes to the German Research Foundation (DFG) for funding the work this paper is based on (projects LE 1805/2 and HA 4438/1). We also thank the reviewers and editor.

This open-access publication was funded

by the University of Göttingen.

Edited by: Dominik Fleitmann

Reviewed by: two anonymous referees

\section{References}

Achterberg, I., Bauerochse, A., Giesecke, T., Metzler, A., and Leuschner, H.: Contemporaneousness of Trackway construction and environmental change: a dendrochronological study in Northwest-German mires, IANSA, 6, 19-29, 2015.

Achterberg, I., Frechen, M., Bauerochse, A., Eckstein, J., and Leuschner, H. H.: The Goettingen tree-ring chronologies of peatpreserved oaks and pines from northwest Germany, ZDGG German Journal of Geosciences (German J. Geol.), 168, 9-19, 2017.

Achterberg, I. E. M., Eckstein, J., Birkholz, B., Bauerochse, A., Leuschner, H. H.: Dendrochronological dates of subfossil pines (Pinus sylvestris L.), relative dates of floating chronology, and peat stratigraphy from site "TOMO_south" at Totes Moor, northwest Germany, PANGAEA, https://doi.pangaea.de/ 10.1594/PANGAEA.884249, 2017.

Achterberg, I. E. M., Eckstein, J., Birkholz, B. et al.: Dendrochronological dates of subfossil pines (Pinus sylvestris L.) of site TOMO_south, https://doi.pangaea.de/10.1594/PANGAEA. 884247, 2017.

Achterberg, I. E. M., Eckstein, J., Birkholz, B. et al.: Peat stratigraphy of site TOMO_south, https://doi.pangaea.de/10. 1594/PANGAEA.884212, 2017.

Achterberg, I. E. M., Eckstein, J., Birkholz, B. et al.: Relative dates of floating chronology of subfossil pines (Pinus sylvestris L.) of site TOMO_south, https://doi.pangaea.de/10.1594/PANGAEA. 884248, 2017.

Arbogast, R. M., Jacomet, S., and Magny, M.: The significance of climate fluctuations for lake level changes and shifts in subsistence economy during the Late Neolithic (4300-2400 BC) in Central Europe, Veg. Hist. Archaeobot., 15, 403-418, 2006.

Bauerochse, A.: Environmental change and its influence on trackway construction and settlement, in: Peatlands, archaeological sites - archives of nature, nature conservation, wise use, edited by: Bauerochse, A. and Hassmann, H., Proceedings of the Peatland Conference 2002 in Hannover, Germany, Rahden/Westfahlen, 66-76, 2003.

Bauerochse, A., Leuschner, H. H., and Metzler, A.: Das Campemoor im Neolithikum, Jahrbuch für das Oldenburger Münsterland 2012, 61. Jahrgang, Heimatbund für das Oldenburger Münsterland, 2012.
Behre, K.-E.: Landschaftsgeschichte Norddeutschlands - Umwelt und Siedlung von der Steinzeit bis zur Gegenwart, Wachholtz Verlag Neumünster, 308 pp., 2008.

Bronk Ramsey, C.: Baysian analysis of radiocarbon dates, Radiocarbon, 51, 337-360, 2009.

Bronk Ramsey, C., van der Plicht, J., and Weninger, B.: "Wiggle matching" radiocarbon dates, Radiocarbon, 43, 381-389, 2001.

Dreslerova, D.: Human Response to Potential Robust Climate Change in the Territory of Bohemia (the Czech Republic), Nat. Sci. Arc., 3, 43-55, 2012.

Eckstein, J., Leuschner, H. H., Bauerochse, A., and Sass-Klaassen, U.: Subfossil bog-pine horizons document climate and ecosystem changes during the Mid-Holocene, Dendrochronologia, 27, 129-146, 2009.

Eckstein, J., Leuschner, H. H., Giesecke, T., Schumilovskikh, L., and Bauerochse, A.: Dendroecological investigations at Venner Moor (northwest Germany) document climate-driven woodland dynamics and mire development in the period 2450-2050 BC, Holocene, 20, 231-244, 2010.

Eckstein, J., Leuschner, H. H., and Bauerochse, A.: Mid-Holocene pine woodland phases and mire development - significance of dendrochronological data from subfossil trees from nortwest Germany, J. Veg. Sci., 22, 781-794, 2011.

Edvardsson, J., Leuschner, H. H., Linderholm, H., and Hammarlund, D.: South Swedish bog pines as indicators of MidHolocene climate variability, Dendrochronologia, 30, 93-103, 2012a.

Edvardsson, J., Linderson, H., Rundgren, M., and Hammarlund, D.: Holocene peatland development and hydrological variability inferred from bog-pine dendrochronology and peat stratigraphy a case study from southern Sweden, J. Quaternary Sci., 27, 553563, $2012 b$.

Edvardsson, J., Poska, A., van der Putten, N., Rundgren, M., Linderson, H., and Hammarlund, D.: Late-Holocene expansion of a south Swedish peatland and its impact on marginal ecosystems: evidence from dendrochronology, peat stratigraphy and paleobotanical data, Holocene, 24, 466-476, 2014.

Edvardsson, J., Stoffel, M., Corona, C., Bragazza, L., Leuschner, H.H., Charman, D. J., and Helama, S.: Subfossil peatland trees as proxies for Holocene palaeohydrology and palaeoclimate, EarthSci. Rev., 163, 118-140, 2016.

Ellenberg, H.: Vegetation Mitteleuropas mit den Alpen, Ulmer Stuttgart, 1096 pp., 1996.

Gunnarson, B., Bogmark, A., and Wastergård, S.: Holocene humidity fluctuations in Sweden inferred from dendrochronology and peat stratigraphy, Boreas, 32, 347-360, 2003.

Holmgren, M., Lin, C.-Y., Murillo, J., Nieuwenhuis, A., Penninkhof, J., Sanders, N., van Bart, T., van Veen, H., Vasander, H., Vollebregt, M., and Limpens, J.: Positive shrub-tree interactions facilitate woody encroachment in boreal peatlands, J. Ecol., 103, 58-66, https://doi.org/10.1111/1365-2745.12331, 2015.

Hughes, P. and Barber, K.: Contrasting pathway to ombrotrophy in three raised bogs in Ireland and Cumbria, England, Holocene, 14, 65-77, 2004.

Kobashi, T., Severinghaus, J. P., Brook, E. J., Barnola, J.-M., and Grachev, A. M.: Precise timing and characterization of abrupt climate change 8200 years ago from air trapped in polar ice, Quaternary Sci. Rev., 26, 1212-1222, 2007. 
Krąpiec, M., Margielewski, W., Korzenń, K., Szychowska-Krąpiec, E., and Łajczak, A.: Late Holocene palaeoclimate variability: The significance of bog pine dendrochronology related to peat stratigraphy, The Puścizna Wielka raised bog case study (Orawa - Nowy Targ Basin, Polish Inner Carpathians), Quaternary Sci. Rev., 148, 192-208, 2016.

Leuschner, H. H., Sass-Klaassen, U., Jansma, E., Baillie, M. G. L., and Spurk, M.: Subfossil European bog oaks: population dynamics and long-term growth depressions as indicators of changes in the Holocene hydro-regime and climate, Holocene, 12, 695-706, 2002.

Leuschner, H. H., Bauerochse, A., and Metzler, A.: Environmental change, bog history and human impact around 2900 B.C. in NW Germany - preliminary results from a dendroecological study of a sub-fossil pine woodland at Campemoor, Dümmer Basin, Veg. Hist. Arc., 16, 183-195, 2007.

Limpens, J., Holmgren, M., Jacobs, C., Van de Zee, S., Karofeld, E., and Berendse, F.: How does tree density affect water loss of peatlands? A mesocosm Experiment, PLOS One, 9, 1-11, 2014.

Magny, M.: Holocene climate variability as reflected by midEuropean lake-level fluctuations and its probable impact on prehistoric human settlements, Quatern. Int., 113, 65-79, 2004.

Meier-Uhlherr, R., Schulz, C., and Luthardt, V.: Steckbriefe Moorsubstrate, 2. unveränd. Aufl., HNE Eberswalde, Berlin, 2015.

Metzler, A.: Moorarchäologie in Niedersachsen, in: Archäologie, Land, Niedersachsen: 25 Jahre Denkmalschutzgesetz - 400.000 Jahre Geschichte, edited by: Fansa, M. and Both, F., Archäologische Mitteilungen aus Nordwestdeutschland, Beiheft 43, Landesmuseum Natur und Mensch Oldenburg, 471-475, 2004.

Moir, A. K., Leroy, S., Brown, D., and Collins, P.: Dendrochronological evidence for a lower water-table on peatland around 3200-3000 BC from subfossil pine in northern Scotland, Holocene, 20, 931-942, 2010.

Nicolussi, K. and Schlüchter, C.: The $8.2 \mathrm{ka}$ event - Calendardated glacier response in the Alps, Geology, 40, 819-822, https://doi.org/10.1130/G32406.1, 2012.

Nicolussi, K., Kaufmann, M., Melvin, T. M., van der Plicht, J., Schießling, P., and Thurner, A.: A 9111 year long conifer treering chronology for the European Alps: a base for environmental and climatic investigations, Holocene, 19, 909-920, 2009.

Overbeck, F.: Das Große Moor bei Gifhorn - im Wechsel hygrokliner und xerokliner Phasen der nordwestdeutschen Hochmoorentwicklung, Niedersächsisches Amt für Landesplanung und Statistik, Veröffentlichungen Reihe A I, Band 41, Walter Dorn Verlag, Bremen-Horn, 1952.

Overbeck, F.: Botanisch-geologische Moorkunde - unter besonderer Berücksichtigung der Moore Nordwestdeutschlands als Quellen zur Vegetations-, Klima- und Siedlungsgeschichte, Karl Wachtelholz Verlag Neumünster, 1975.

Petzelberger, B., Behre, K.-E., and Geyh, M.: Beginning and spread of raised bogs Northwest Germany - first results of a new project, Telma, 29, 21-38, 1999.

Reimer, P., Baillie, M., Bard, E., Bayliss, A., Beck, J., Blackwell, P., Bronk Ramsey, C., Grootes, P., Guilderson, T., Haflidason, H., Hajdas, I., Hatté, C., Heaton, T., Hoffmann, D., Hogg, A., Hughen, K., Kaiser, K., Kromer, B., Manning, S., Niu, M., Reimer, R., Richards, D., Scott, E., Southon, J., Staff, R., Turney, C., and van der Plicht, J.: IntCal13 and Marine 13 radiocar- bon age calibration curves, 0-50,000 years cal BP, Radiocarbon, 55, 1869-1887, 2013.

Riemer T.: Über die Varianz von Jahrringbreiten - Statistische Methoden für die Auswertung der jährlichen Dickenzuwächse von Bäumen unter sich ändernden Lebensbedingungen, Berichte des Forschungszentrums Waldökosysteme, Reihe A, 121, 1-375, 1994.

Rinn, F.: TSAP-Win: Time Series Analysis and Presentation for Dendrochronology and related Applications, Version 0.55 User reference, Heidelberg, Germany, 2003.

Schmidt, B., Gruhle, W., and Rück, O.: Klimaextreme in Bandkeramischer Zeit (5300 bis 5000 v. Chr.), Interpretation dendrochronologischer und archäologischer Befunde, Archäologisches Korrespondenzblatt, 34, 303-308, 2004.

Schweingruber, F.: Tree Rings - Basics and Application of Dendrochronology, 276 S. D. Reidel Publishing Company, Dordrecht, Holland, 1988.

Seppä, H., Hammarlund, D., and Antonsson, K.: Low-frequency changes in temperature and effective humidity during the Holocene in south-central Sweden: implications for atmospheric and oceanic forcings of climate, Clim. Dynam., 25, 285-297, https://doi.org/10.1007/s00382-005-0024-5, 2005.

Shumilovskikh, L., Schlütz, F., Achterberg, I., Kvitkina, A., Bauerochse, A., and Leuschner, H. H.: Pollen as a nutrient source in Holocene ombrotrophic bogs, Rev. Palaeobot. Palyno., 221, 171178, 2015.

Spurk, M., Leuschner, H., Baillie, M., Briffa, K., and Friedrich, M.: Depositional frequency of German subfossil oaks: climatically induced fluctuations in the Holocene, Holocene 12, 707-715, 2002.

Stenzel, V.: Dendroökologische Untersuchungen zum räumlichzeitlichen Wachstum eines subfossilen Kiefernwaldes im Toten Moor (bei Neustadt am Rübenberge in Niedersachsen), Bachelorarbeit, Abteilung Palynology und Klimadynamik, Albrecht-vonHaller-Institut für Pflanzenwissenschaften, Biologische Fakultät, Universität Göttingen, 2013.

Tahvanainen, T.: Abrupt ombrotrophication of a boreal aapa mire triggered by hydrological disturbance in the catchment, J. Ecol., 99, 404-415, 2011.

Thomas, E., Wolff, E., Mulvaney, R., Steffensen, J., Johnsen, S., Arrowsmith, C., White, J., Vaughn, B., and Popp, T.: The 8.2 ka event from Greenland ice cores, Quaternary Sci. Rev., 26, 70-81, 2007.

Torbenson, M., Plunkett, G.,Brown, D., Pilcher, J., and Leuschner, H. H.: Asynchrony in key Holocene chronologies: Evidence from Irish bog pines, Geology, 43, 799-802, 2015.

Turney, C., Baillie, M., and Palmer, J.: Holocene climatic change and past Irish societal response, J. Archaeol. Sci., 33, 34-38, 2006.

Veski, S., Seppä, H., and Ojala, A.: Cold event at 8200 yr B.P. recorded in annually laminated lake sediments in eastern Europe, Geology, 32, 681-684, 2004.

von Bülow, K.: Die Bedeutung der Versumpfung für die Entstehung von Hochmooren in Deutschland, Geol. Rund., 26, 277284, 1935.

Zackrisson, O., Nilsson, M.-C., Steijlen, I., and Hörnberg, G.: Regenration pulses and climate-vegetation interactions in nonpyrogenic boral Scots pine stands, J. Ecol., 83, 469-483, 1995. 